\title{
Energy saving renovation: analysis of critical factors at the building level
}

\author{
R. Vreenegoor ${ }^{1}$, B. de Vries $^{1} \&$ J. Hensen ${ }^{2}$ \\ ${ }^{1}$ Design and Decision Support Systems, \\ Department of Architecture, Building and Planning, \\ Eindhoven University of Technology, The Netherlands \\ ${ }^{2}$ Building Physics and Systems, \\ Department of Architecture, Building and Planning, \\ Eindhoven University of Technology, The Netherlands
}

\begin{abstract}
To accelerate energy saving in the built environment, housing associations should apply low-energy techniques in existing houses that are in need of renovation. Because of a lack of knowledge it is difficult for housing associations to determine which low-energy technique has the best results for energy consumption and $\mathrm{CO}_{2}$-emissions. In this research a decision support tool will be developed with a new energy performance calculation method at district level including aspects such as houses, transport and households. In this paper we focus on the critical factors at the building level that should be included in a district data model. Therefore we have executed a screening analysis to indicate what these critical factors are.
\end{abstract}

Keywords: design support, energy performance simulation, screening analysis, building model.

\section{Introduction}

\subsection{We need to save energy}

More and more people realize we need to save energy. Firstly because our fossil energy sources are decreasing. The estimated years of production for oil, gas and coal are 45, 65 and 200 years respectively [1,2]. Secondly we need to save energy because of the climate change. Our daily energy use, based on fossil fuels 
(gas, oil, coal), causes severe damage to the environment. To restrict the climate change a large number of countries have made agreements on $\mathrm{CO}_{2}$ reduction [3]. The EU has the ambition to reduce $\mathrm{CO}_{2}$-emissions by $20 \%$ in 2020 compared to 1990 [4].

All sectors of industry need to take appropriate action to reduce the use of fossil energy. In the Netherlands, the built environment is responsible for $40 \%$ of the total energy consumption [5], which makes exploration of the possibilities to reduce energy in the built environment relevant.

\subsection{Energy saving potential in existing houses}

The largest energy savings are feasible in the existing building stock. A house built before 1945 uses almost twice as much energy for heating in comparison to a house built after 2006 [8,9]. Housing associations own a large number of houses and renovate large scale projects, accelerating energy reduction in the existing building stock. They have a positive attitude towards energy saving techniques but name a lack of knowledge as an important barrier for applying them [5]. When renovating a whole street or neighbourhood at once, the amount of energy saving solutions is larger compared to consideration of just one building. District energy supply systems become an interesting alternative. A comparison between individual and district energy supply systems in the field of energy saving and cost-effectiveness, can support the housing associations in choosing the optimal system.

\subsection{Objective}

The objective is to develop a district evaluation model based on energy performance, costs and comfort to support housing associations in choosing the optimal renovation solution. Figure 1 shows a schematization of the evaluation model.

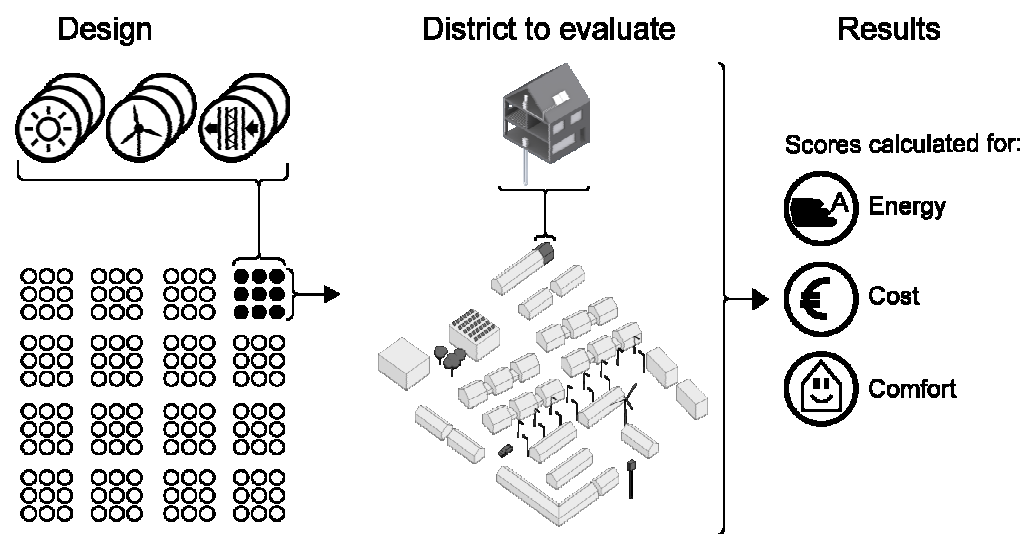

Figure 1: $\quad$ Schematization district evaluation model. 
On the left, single renovation solutions, like solar energy and insulation, are arranged in a solution package. These packages are applied to the district in need of renovation. Next, the evaluation model will return scores for energy performance, costs and comfort. Comparison of these three results among the renovation packages is difficult. After all, which renovation solution is better the one with a good energy performance, high costs and moderate comfort or the one with a moderate energy performance, low costs and high comfort? To return the user a top ten of renovation solutions, an optimization technique will be used.

\subsection{Deliverables}

The following methods and techniques will be used or developed and eventually implemented in a prototype evaluation model:

1. Energy and comfort performance calculation at district level, based on existing methods at building level like EPN [8], EPA [7].

2. District data model based on existing methods like IFC [13], HDH [14].

3. Residents' preferences measurement method for the determination of the preferred design solution, based on existing methods like semantic differentials, conjoint analysis.

4. Optimization technique for the determination of the optimal design solution.

In this paper the development of an energy performance calculation method at district level will be discussed.

\section{District energy performance calculation}

In a house the energy needed for heating is calculated through the total heat loss minus the heat gain divided by the efficiency of the heating system. Based on the usable area of the house and system efficiency, the energy needed for hot water, ventilation and lighting are determined. At district level other aspects become part of the energy performance calculation these are discussed in the next paragraphs.

\subsection{Average district energy consumption}

To determine the aspects to take into account in the energy performance calculation at district level, the average energy consumption and $\mathrm{CO}_{2}$-emissions of aspects like houses, streetlights, and transport are used. Table 1 shows houses have the largest contribution to the energy consumption in a district. The value shown in table 1 is the average energy use of the Dutch housing stock and considers energy needed for heating, hot water and appliances [9].

The amount of $\mathrm{CO}_{2}$-emissions produced by transportation strongly depends on the type of transport and the travelling distance. The $\mathrm{CO}_{2}$-emissions produced by transport [10], shown in table 1, are based on an average household consisting of 2,3 persons. Transport by car, assuming an average travelling distance of $15.500 \mathrm{~km}$ per year, has the second largest contribution to the $\mathrm{CO}_{2}$-emissions in 
Table 1: Average energy consumption and $\mathrm{CO}_{2}$-emissions in the Netherlands per year.

\begin{tabular}{|l|l|l|l|l|}
\hline Aspect & Object & Consumption & $\begin{array}{l}\mathrm{CO}_{2} \text {-emissions } \\
\text { (ton) }\end{array}$ & Year \\
\hline House & Electricity & $3346 \mathrm{kWh}$ & 1,9 & 2004 \\
\hline & Gas & $1736 \mathrm{~m}^{3}$ & 3,1 & 2004 \\
\hline Transport & Car & $15.500 \mathrm{~km}$ & 3,0 & 2008 \\
\hline & $\begin{array}{l}\text { Public } \\
\text { transport } \\
\text { - Train } \\
\end{array}$ & $894 \mathrm{~km}$ & 0,2 & 2008 \\
& $\begin{array}{l}\text { Bus, tram, } \\
\text { metro }\end{array}$ & $409 \mathrm{~km}$ & & \\
\hline & Airplane & $1300 \mathrm{~km}$ & 0,8 & \\
\hline Streetlights & Electricity & $150 \mathrm{~kW}$ & 0,085 & 2008 \\
\hline
\end{tabular}

a district. The amount of electricity needed for streetlights, given per house [11], is very small compared to the contribution of the houses and transportation and could therefore be left out of the district energy performance calculation.

\subsection{Aspects to take into account}

The previous paragraph concluded that the aspects house and transport have the largest contribution to the energy consumption and $\mathrm{CO}_{2}$-emissions in a district and should therefore be part of the district energy performance calculation. The systems and building constructions in the district, households and their transport will be evaluated in the new district energy calculation method.

\subsubsection{House}

To compute the energy consumption for systems and building constructions in the district, existing Dutch calculation methods will be used. The first prototype of the district evaluation model will consist of the existing Dutch calculation methods EPA (Energy Performance Advice). The EPA is used in the Netherlands to compute the energy performance of a building and to create an energy label, which is required when selling or renting certain house-, commercial or industrial buildings in the Netherlands.

\subsubsection{Household}

Because existing energy performance calculation methods consider mainly an average household with a certain user behaviour, the actual and calculated energy consumption can differ. The user behaviour has a large influence on the eventual energy consumption. Research shows differences in energy consumption between households living in the same houses [12]. Therefore the household is included in the new district energy performance calculation.

\subsubsection{Transport}

To predict the type of transport and transportation distance a Dutch simulation model will be used. This model is capable of predicting the transport activities 
for a household. In the next section we describe which models are used and how they are integrated into one district model.

\subsection{Screening analysis EPA}

The EPA calculation method needs 99 input values to compute among others the energy index, which describes a score for energy performance (smaller = better). A screening analysis is performed to find the most critical factors at building level. The screening technique evaluates a single input value. For each single input a minimum and maximum value is used to compute the influence on the energy index, total energy use and $\mathrm{CO}_{2}$-emissions.

Some of the single input values are related to others, like the usable floor area and the façade area, which makes a single input evaluation not useful. To research the influence of these input values on the output, data of reference houses is being used [6]. This data describes average Dutch houses divided into building type and building period. The dependent input values receive fixed values from the reference houses while the independent input values are varied.

Table 2 shows per input variable the type (independent or dependent), minimum and maximum value. The total amount of variables shown in this table is lower than the amount mentioned earlier because for the first screening analysis the district systems are not evaluated and the input values concerning the front, back, left and right façade are combined in the table. For each dependent variable, the variables it depends upon are noted between brackets in the second column. Some input values have both dependent and independent characters.

\section{Results screening analysis}

In total nine different reference houses, consisting of five building types and four building periods for a row house, are used in the screening analysis. For each reference house the independent single input influence on the output is computed, the results are discussed in 3.1. The influence of the dependent variables is determined through comparison of reference houses with various building periods for a row house and various building types. These results are discussed in paragraph 3.2 and 3.3.

\subsection{Single input influence}

The energy index, total energy use and $\mathrm{CO}_{2}$-emissions are computed per single input variable for the reference, minimum and maximum value. In case of a large difference between the output results caused by the minimum and maximum input value, the influence on the output is large. The most important input values are related to thermal insulation, residents' behaviour and building systems. In the following paragraphs the results of the input variables concerning thermal insulation, residents and building systems will be discussed in more detail. 
Table 2: $\quad$ Variables in EPA calculation.

\begin{tabular}{|c|c|c|c|c|}
\hline & Variable & Type & Minimum & Maximum \\
\hline 1. & Average inside temperature & $\mathrm{I}$ & $10^{\circ} \mathrm{C}$ & $20^{\circ} \mathrm{C}$ \\
\hline 2. & Ventilation correction factor & I & 0,5 & 1,5 \\
\hline 3. & Internal heat production & $\mathrm{I}$ & $1,0 \mathrm{~W} / \mathrm{m}^{2}$ & $15 \mathrm{~W} / \mathrm{m}^{2}$ \\
\hline 4. & Amount of residents & I & 1 person & 10 persons \\
\hline 5. & Usable area $(8,13,17,20,23)$ & $\mathrm{D}$ & $\mathrm{n} / \mathrm{a}$ & $\mathrm{n} / \mathrm{a}$ \\
\hline 6. & House type $(5,8,13,17,20,23)$ & $\mathrm{D}$ & $\mathrm{n} / \mathrm{a}$ & $\mathrm{n} / \mathrm{a}$ \\
\hline 7. & Roof type (6) & $\mathrm{I}$ & $\mathrm{n} / \mathrm{a}$ & $\mathrm{n} / \mathrm{a}$ \\
\hline 8. & Façade, opaque area $(5,6)$ & $\mathrm{D}$ & $1 \mathrm{~m}^{2}$ & total $-1 \mathrm{~m}^{2}$ \\
\hline 10. & Façade, opaque insulation & $\mathrm{I}$ & $0,1 \mathrm{~m}^{2} \mathrm{~K} / \mathrm{W}$ & $8,0 \mathrm{~m}^{2} \mathrm{~K} / \mathrm{W}$ \\
\hline 11. & Façade, boundary condition & $\mathrm{I}$ & outside & other room \\
\hline 12. & Façade, orientation & I & North & South \\
\hline 13. & Façade, transparent area $(5,6)$ & $\mathrm{D}$ & $1 \mathrm{~m}^{2}$ & total $-1 \mathrm{~m}^{2}$ \\
\hline 14. & Façade, transparent insulation & I & $6,0 \mathrm{~W} / \mathrm{m}^{2} \mathrm{~K}$ & $1,0 \mathrm{~W} / \mathrm{m}^{2} \mathrm{~K}$ \\
\hline 15. & Façade, sun access factor & $\mathrm{I}$ & 0,3 & 0,8 \\
\hline 16. & Glass, boundary condition & $\mathrm{I}$ & outside & other room \\
\hline 17. & Floor, area $(5,6)$ & $\mathrm{D}$ & $\mathrm{n} / \mathrm{a}$ & $\mathrm{n} / \mathrm{a}$ \\
\hline 18. & Floor, thermal insulation & $\mathrm{I}$ & $0,1 \mathrm{~m}^{2} \mathrm{~K} / \mathrm{W}$ & $8,0 \mathrm{~m}^{2} \mathrm{~K} / \mathrm{W}$ \\
\hline 19. & Floor, boundary condition & $\mathrm{I}$ & ground & outside \\
\hline 20. & Roof, opaque area $(5,6)$ & $\mathrm{D}$ & $\mathrm{n} / \mathrm{a}$ & $\mathrm{n} / \mathrm{a}$ \\
\hline 21. & Roof, opaque insulation & $\mathrm{I}$ & $0,1 \mathrm{~m}^{2} \mathrm{~K} / \mathrm{W}$ & $10 \mathrm{~m}^{2} \mathrm{~K} / \mathrm{W}$ \\
\hline 22. & Roof, transparent orientation & $\mathrm{I}$ & North & South \\
\hline 23. & Roof, transparent area $(5,6)$ & $\mathrm{D}$ & $\mathrm{n} / \mathrm{a}$ & $\mathrm{n} / \mathrm{a}$ \\
\hline 24. & Roof, transparent insulation & $\mathrm{I}$ & $6,0 \mathrm{~W} / \mathrm{m}^{2} \mathrm{~K}$ & $1,0 \mathrm{~W} / \mathrm{m}^{2} \mathrm{~K}$ \\
\hline 25. & Roof, sun access factor & I & 0,3 & 0,8 \\
\hline 26. & Airtightness & $\mathrm{I}$ & filled & un filled \\
\hline 27. & Heating system, type & $\mathrm{I}$ & local & heatpump \\
\hline 28. & Electronic ignition (27) & $\mathrm{I} / \mathrm{D}$ & yes & no \\
\hline 29. & Inside building envelope & $\mathrm{I}$ & yes & no \\
\hline 30. & Supply temperature (27) & $\mathrm{I} / \mathrm{D}$ & $<35^{\circ} \mathrm{C}$ & $>55^{\circ} \mathrm{C}$ \\
\hline 31. & Optimal control & I & yes & no \\
\hline 32. & Pipes in unheated rooms & $\mathrm{I}$ & yes & no \\
\hline 33. & Insulated pipes (32) & $\mathrm{D}$ & yes & no \\
\hline 34. & Hot water system, type & $\mathrm{I}$ & efficient & electric boiler \\
\hline 35. & Hot water system, location & $\mathrm{I}$ & nearby & far away \\
\hline 36. & Kitchen boiler & $\mathrm{I}$ & yes & no \\
\hline 37. & Dishwasher & $\mathrm{I}$ & yes & no \\
\hline 38. & Shower & $\mathrm{I}$ & yes & no \\
\hline 39. & Water-saving showerhead & $\mathrm{I}$ & yes & no \\
\hline 40. & Bath & $\mathrm{I}$ & yes & no \\
\hline 41. & Ventilation system & I & natural & mechanic \\
\hline 42. & Heat recovery efficiency (41) & $\mathrm{I} / \mathrm{D}$ & $60 \%$ & $95 \%$ \\
\hline 43. & Fan type (41) & $\mathrm{I} / \mathrm{D}$ & $\mathrm{DC}$ & $\mathrm{AC}$ \\
\hline
\end{tabular}


Table 2: $\quad$ Continued.

\begin{tabular}{|l|l|l|l|l|}
\hline & Variable & Type & Minimum & Maximum \\
\hline 44. & Solar boiler, type & I & none & combination \\
\hline 45. & Contribution heating system & I & yes & no \\
\hline 46. & Contribution hot water system & I & yes & no \\
\hline 47. & Solar boiler, area (44, 45, 46) & D & $0 \mathrm{~m}^{2}$ & $5,5 \mathrm{~m}^{2}$ \\
\hline 48. & Solar boiler, orientation & I & North & South \\
\hline 49. & Solar boiler, angle & I & $90^{\circ}$ & $45^{\circ}$ \\
\hline 50. & Solar panel, type & I & amorphous & crystalline \\
\hline 51. & Solar panel, area & I & $0 \mathrm{~m}^{2}$ & $10 \mathrm{~m}^{2}$ \\
\hline 52. & Solar panel, orientation & I & North & South \\
\hline 53. & Solar panel, angle & I & $90^{\circ}$ & $30^{\circ}$ \\
\hline
\end{tabular}

\subsubsection{Residents' behaviour variables}

The average inside temperature has the largest influence on the output, based on the chosen minimum and maximum value in table 2 . The minimum value is chosen very low, in practice this value will be more close to $16^{\circ} \mathrm{C}$. In that case the amount of influence on the output is similar to the other input variables concerning residents' behaviour. An increasing average inside temperature, amount of residents and ventilation correction factor gives a higher energy performance. The opposite applies to the internal heat production. This was to be expected, because a higher internal heat production lowers the heat demand and therefore the energy use.

\subsubsection{Building construction variables}

The influence of the percentage of glass in the façade depends on the orientation. Increase of the glass area on the north decreases the energy index with 0,04 , while on the south the energy index increases with 0,25 when the glass area is increased with the same amount. The influence of the thermal insulation of the roof has the largest influence followed by the façade, floor and finally glass insulation. It looks like the area of the construction is important for the result. The results for the maximum thermal insulation are situated close to each other.

\subsubsection{Building system variables}

Independent input variables concerning building systems are among others a heating, hot water and ventilation system. The maximum value represents a system with high energy efficiency and has therefore better results for the energy performance. The efficiency of the heating system has the largest influence on the output.

\subsection{Housing type influence}

The comparison of five different reference houses, consisting of a row house, detached house, semi-detached house, maisonette and apartment, shows the influence of dependent input values. The main differences between the five building types are the usable floor area, amount of residents, building envelope area and percentage of glass in the façades. To exclude differences caused by 
insulation, the five reference houses are all from the same building period $(<$ 1966). Table 3 shows the results for the energy index, total energy use and $\mathrm{CO}_{2}$ emissions. Because of the large differences between the five building types, it can be stated that the dependent input values influence the output.

Besides differences between the building types caused by the dependent variables, the independent variables appear to have different influence on the

Table 3: $\quad$ Results of five building types.

\begin{tabular}{|l|c|c|c|}
\hline Building type & Energy index (-) & Total energy use (MJ) & $\mathrm{CO}_{2}$-emissions $(\mathrm{kg})$ \\
\hline Apartment & 1,71 & 41300 & 2172 \\
\hline Maisonette & 1,60 & 55705 & 2893 \\
\hline Row house & 1,68 & 65266 & 3382 \\
\hline Semi-detached & 2,10 & 108115 & 5560 \\
\hline Detached & 1,98 & 190925 & 9831 \\
\hline
\end{tabular}

output. Some of them have equal results for each building type, this applies to the thermal insulation of the roof. Others show an increasing influence on the output in case of a bigger house, like the average inside temperature and the heating system. But most of the input values show an increasing influence when the house is enlarged.

\subsection{Building period influence}

The comparison of four different reference row houses, built before 1946, between 1946-1965, 1976-1979 and 1989-2000, shows the influence of dependent input values. The main differences between the building periods are the thermal insulation and the presence of a bath. To exclude the differences caused by the size of the houses, the building type is kept the same. Table 4 shows the results for the energy index, total energy use and $\mathrm{CO}_{2}$-emissions. Because of the differences between the four building periods, it can be stated that the dependent input values influence the output. Paragraph 3.1.2 already mentioned the influence of the thermal insulation on the output.

Table 4: $\quad$ Results for four building periods.

\begin{tabular}{|l|c|c|c|}
\hline Building period & Energy index (-) & Total energy use (MJ) & $\mathrm{CO}_{2}$-emissions $(\mathrm{kg})$ \\
\hline$<1946$ & 1,72 & 69199 & 3582 \\
\hline $1946-1965$ & 1,68 & 65266 & 3382 \\
\hline $1976-1979$ & 1,42 & 59779 & 3112 \\
\hline $1989-2000$ & 1,20 & 49261 & 2610 \\
\hline
\end{tabular}

Besides differences between the building periods caused by the dependent variables, the independent input values appear to have different influence on the output. Most of them have equal results for each building period. The average inside temperature, floor boundary conditions and heating system show a decreasing influence on the output when the building period is younger. 


\section{Conclusion}

\subsection{Independent input}

Nine different reference houses, consisting of five building types and four building periods for a row house, are used in the screening analysis. Table 5 shows the most important independent variables in the EPA calculation.

Table 5: $\quad$ Most important (independent) input variables EPA calculation.

\begin{tabular}{|l|l|c|c|c|}
\hline & Input & Energy index & $\begin{array}{c}\text { Total energy } \\
\text { use }\end{array}$ & $\begin{array}{c}\mathrm{CO}_{2^{-}} \\
\text {emissions }\end{array}$ \\
\hline 1 & Roof, opaque insulation & 0,981 & 0,980 & 0,953 \\
\hline 2 & $\begin{array}{l}\text { Average inside } \\
\text { temperature }\end{array}$ & 0,885 & 0,885 & 0,862 \\
\hline 3 & Façade, opaque insulation & 0,578 & 0,578 & 0,560 \\
\hline 4 & Internal heat production & 0,445 & 0,473 & 0,459 \\
\hline 5 & Ind. heating system, type & 0,448 & 0,448 & 0,547 \\
\hline 6 & $\begin{array}{l}\text { Ventilation correction } \\
\text { factor }\end{array}$ & 0,314 & 0,315 & 0,306 \\
\hline 7 & Floor, boundary condition & 0,269 & 0,405 & 0,303 \\
\hline 8 & Amount of residents & 0,227 & 0,239 & 0,233 \\
\hline 9 & $\begin{array}{l}\text { Façade, transparent } \\
\text { insulation }\end{array}$ & 0,167 & 0,167 & 0,162 \\
\hline 10 & Façade, transparent area & 0,145 & 0,146 & 0,141 \\
\hline 11 & Ventilation system & 0,131 & 0,131 & 0,136 \\
\hline 12 & Hot water system, type & 0,128 & 0,130 & 0,138 \\
\hline
\end{tabular}

For each independent variable, the minimum and maximum value for the energy index, total energy use and $\mathrm{CO}_{2}$-emissions is determined to find the most important independent variables. The difference is divided by the reference value to compare the results among the independent variables. Eqn 1 gives an example of the variable 'thermal insulation of the roof' for the reference row house built before 1946 .

$$
\frac{\left|E I_{\min }-E I_{\max }\right|}{E I_{\text {ref }}}=\frac{|3,21-1,58|}{1,72}=0,95
$$

Explanation components stated within eqn (1):

$\mathrm{EI}_{\text {min }}=$ energy index in case of the minimum input value;

$\mathrm{EI}_{\max }=$ energy index in case of the maximum input value;

$\mathrm{EI}_{\text {mref }}=$ energy index in case of the reference input value.

Because the influence of the independent variables differs per building type and building period, the average score for the nine reference houses is shown in table 5. The higher the score, the larger the influence of the variable on the output. 


\subsection{Dependent input}

Data of reference houses are used to vary the dependent variables useable floor area, building envelope area and house type. The screening results discussed in paragraph 3.2 and 3.3 show the dependent variables influence the output. These results only show the size of influence on the output of a group of dependent variables. At this stage it is not possible to determine the single influence of each dependent variable. Therefore, future work will consist of a sensitivity analysis that considers multiple variables.

\section{References}

[1] Ministerie van Economische Zaken, Derde Energienota, SDU Uitgevers, Den Haag, 1995.

[2] World Energy Council, Survey of energy resources, Elsevier, Oxford, 2004.

[3] Alley, R., Berntsen, T., Bindoff, N., Chen, Z., Chidthaisong, A., Friedlingstein, P., et al., Climate Change 2007: the physical science basis, The IPPCC 4th assessment report, 2007.

[4] Wesselink, L.G., Eerens, H. \& Vis, J., EU 2020 climate target: $20 \%$ reduction requires five-fold increase in impact of $\mathrm{CO}_{2}$ policies, Netherlands Environmental Assessment Agency (MNP), Bilthoven, 2008.

[5] Sunikka, M.M., Policies for improving energy efficiency in the European housing stock, IOS Press BV, Amsterdam, 2006.

[6] SenterNovem, Voorbeeldwoningen bestaande bouw 2007, SenterNovem, Sittard, 2007.

[7] DGMR, Formulestructuur EI en maatwerkadvies woningbouw, SenterNovem, Sittard, 2006.

[8] NEN 5128:2004, Energy performance of residential functions and residential buildings - Determination method, 2004.

[9] SenterNovem, Cijfers en tabellen 2007, SenterNovem, Sittard, 2007.

[10] Dutch independent corporation 'milieu centraal' offering environmental information, www.milieucentraal.nl/

[11] Rooijers, F., Moorman, S., Dulk den, F. \& Buitenhuis, H., EPL bestaande woningbouw; systematiek, CE, Delft, 2001.

[12] Soethout, L.L., Peitsman, H.C., Shemeikka, J., Haakana, M., Soitinaho, U. and Tessier, Ph., Improving municipal energy management by motivational measures and knowledge transfer, TNO, Delft, 1999.

[13] International Alliance for Interoperability, information on building model IFC, www.iai-international.org

[14] Dutch webpage 'Het digitale huis' on building model, www.hetdigitalehuis.nl 